\title{
The effect of Mediterranean thyme (Thymbra spicata L. var. spicata) essential oil on fattening performance and ruminal parameters in lamb
}

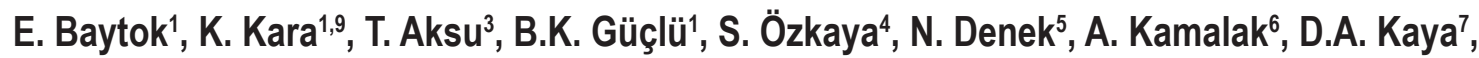 \\ S.E. Önel ${ }^{8}$ and A. Akçay ${ }^{2}$ \\ Erciyes University, Faculty of Veterinary Medicine \\ ${ }^{1}$ Department of Animal Nutrition and Nutritional Diseases, ${ }^{2}$ Department of Biostatistics, 38280, Kayseri, Turkey \\ ${ }^{3}$ Yüzüncü Y॥ University, Faculty of Veterinary Medicine, Department of Animal Nutrition and Nutritional Diseases, 65080, Van, Turkey \\ ${ }^{4}$ Süleyman Demirel University, Faculty of Agriculture, Department of Animal Science, 32260, Isparta, Turkey \\ ${ }^{5}$ Harran University, Faculty of Veterinary Medicine, Department of Animal Nutrition and Nutritional Diseases, 63000, Şanllurfa, Turkey \\ ${ }^{6}$ Sütçü Imam University, Faculty of Agriculture, Department of Animal Science, 46100, Kahramanmaraş, Turkey \\ Mustafa Kemal University, ${ }^{7}$ Faculty of Agriculture, Department of Field Crops, ${ }^{8}$ Vocational School of Samandağ, \\ Department of Plant and Animal Production, 31060, Hatay, Turkey
}

KEY WORDS: ammonia, carvacrol, performance, volatile fatty acids, lambs

Received: 19 January 2017

Revised: $\quad 29$ August 2017

Accepted: 22 November 2017

${ }^{9}$ Corresponding author:

e-mail: kanberkara@erciyes.edu.tr

\begin{abstract}
The aim of this study was to investigate the effect of dietary supplementation of Thymbra spicata L. var. spicata (TS) essential oil (10 or $15 \mu \mathrm{l} \cdot \mathrm{kg}^{-1}$ live weight (LW)) on growth performance (LW, LW gain, feed intake) and rumen parameters (volatile fatty acids (VFA)) and ammonia levels, and $\mathrm{pH}$ ) in lambs. The experiment lasted 56 days, including 14 days of adaptation and 42 of experimental period. The TS essential oil was extracted from the leaves harvested at the beginning of plant flowering and contained: $66.86 \%$ carvacrol, $12.18 \%$ p-cymene, $10.73 \%$ y-terpinene and $2.77 \%$ thymol. The addition of TS essential oil to concentrate feed did not affect final LW, LW gain, feed intake or feed conversion ratio $(P>0.05)$. Molar concentrations $\left(\mathrm{mmol} \cdot \mathrm{I}^{-1}\right)$ of total VFA and acetic $(A)$, butyric $(B)$ and propionic $(P)$ acids, and levels of $\mathrm{pH}$ and ammonia-nitrogen $\left(\mathrm{NH}_{3}-\mathrm{N}\right)$ in rumen fluid were also not affected by TS essential oil inclusion $(P>0.05)$. However, the proportion of $A$ and $(A+B): P$ ratio in rumen fluid VFA increased linearly $(P<0.01)$ with increasing TS essential oil doses, whereas the $P$ proportion decreased linearly $(P=0.008)$. So, it could be suggested that TS essential oil enhanced the concentration of selected VFA in rumen fluid through a positive effect on feed digestion in the rumen. In particular, the linear increase in $A$ and $(A+B): P$ ratio could have enhanced fibrolytic effect in the rumen ecosystem. It was concluded that different doses and longer terms of use of TS essential oil should be further investigated in in vivo studies.
\end{abstract}

\section{Introduction}

In southern Europe and the Eastern Mediterranean, several species of Origanum, Satureja, Thymbra, Thymus and Corydothymus due to their similar smell are known as thyme (Başer, 1995). Besides bay leaf, thyme is the most often exported aromatic plant from Turkey (Ünlü et al., 2009). In the flora of Turkey, 31 taxa consisting of 23 species of Origanum are registered (Önenç, 2008). Thymbra, Origanum, 
Satureja, Thymus and Corydothymus genera contain carvacrol, thymol or both phenols that are the main components of their essential oils (Başer et al., 1994).

Thymbra spicata (TS) L. belongs to the Lamiaceae family and 4 taxa of this plant exist in Turkey, namely Thymbra spicata var. spicata and intricata, Thymbra sintenisii var. sintenisii and isaurica with essential oil content of $1.0-3.4 \%, 1.4-2.7 \%, 1.5 \%$, and $1.6 \%$, respectively (Başer, 2002). The major component of their essential oils is carvacrol (Başer, 2002; Ünlü et al., 2009). The TS essential oil was reported to consist of $53.1 \%$ oxygenated compounds, $25.7 \%$ monoterpene hydrocarbons, $4.4 \%$ sesquiterpenes and $14.1 \%$ p-cymene (Hanc1 et al., 2003). The leaves of TS have been traditionally used in meat products and beverages, but also as ingredients of certain medicines due to their antimicrobial and antiseptic properties (Hanc1 et al., 2003; Ünlü et al., 2009).

Supplementing essential oils and aromatic plants to ruminant diets improve the digestion, resulting in reduced methanogenesis and nitrogen excretion. Besides, the antioxidative effect, such substances contribute to the stability and palatability of animal diet and so, due to reduced oxidation, an improved shelf-life and quality of animal products (Franz et al., 2010). In our previous study the effect of TS essential oil at different levels $\left(40,80,120,160\right.$ and $200 \mathrm{mg} \cdot 1^{-1}$ of rumen liquids) on in vitro gas production of dairy and beef cattle fed total mixed rations was evaluated (Baytok et al., 2013). It was demonstrated that TS essential oil, especially at the level of $80 \mathrm{mg} \cdot 1^{-1}$, exerts a positive effect on the in vitro feed digestibility (Baytok et al., 2013). Nowadays, it is very important to reduce ruminal methane emission in order to prevent global warming and gross energy losses of feed (Kara, 2015; Kara et al., 2015). In the aforementioned study, the 80 and $120 \mathrm{mg} \cdot 1^{-1}$ doses of TS essential oil were found to reduce methane production by 9.45 and $34.90 \%$, respectively (Baytok et al., 2013).

The purpose of the present study was to determine the effect of TS essential oil dietary supplementation, which exerts an in vitro anti-methanogenic effect, on growth performance (live weight (LW), LW gain, feed intake) and rumen parameters (volatile fatty acids and ammonia levels, and $\mathrm{pH}$ ) in lambs. The obtained results may be helpful in providing information about TS essential oil usage in livestock.

\section{Material and methods}

The study was approved by The Local Ethics Committee of Erciyes University (ERU-HADYEK), Kayseri (Turkey) on 14 December 2011 (No. 11/134).

\section{Plant samples and extraction}

In the study, Thymbra spicata L. var. spicata plants naturally grown in the province of Hatay (Turkey) were used for essential oil extraction. The plants were collected in the flowering stage and samples were further dried at $35{ }^{\circ} \mathrm{C}$ in the laboratory. Essential oil was extracted by using steam distillation, and its chemical composition was determined by gas chromatography-mass spectrometry (GCMS) technique. Analysis of the essential oil was carried out using an ISQ ${ }^{\mathrm{TM}}$ Single Quadrupole GC-MS System (Thermo Fisher Scientific, Waltham, MA, USA) equipped with autosampler and TR-5MS capillary column (5\% phenyl polysilphenylene-siloxane, length $30 \mathrm{~m}$, diameter $0.25 \mathrm{~mm}$, film thickness $0.25 \mu \mathrm{m})$. Helium $(99.9 \%)$ was used as the carrier gas at a flow rate of $1 \mathrm{ml} \cdot \mathrm{min}^{-1}$; ionization energy was $70 \mathrm{eV}$. Mass range was m/z 1.2-1100. The used data acquisition method was scan mode. The MS transfer line temperature was $250^{\circ} \mathrm{C}$, MS ionization source temperature was $220^{\circ} \mathrm{C}$, and the injection port temperature was $220^{\circ} \mathrm{C}$. The samples were injected with 1:250 split ratio. The injection volume was $1 \mu \mathrm{l}$. The oven temperature was programmed to increase from $50{ }^{\circ} \mathrm{C}$ to $220{ }^{\circ} \mathrm{C}$ at a rate $3{ }^{\circ} \mathrm{C} \cdot \mathrm{min}^{-1}$. The structure of each compound was identified by comparison to its mass spectrum (Wiley, Hoboken, NJ, USA) and data were handled using the Xcalibur Software (Thermo Fisher Scientific, Waltham, MA, USA).

\section{Animal management}

In the study, 15 male 3-month old lambs belonging to the Akkaraman breed which is a local sheep breed in Turkey's Central Anatolia Region were used. The animals were kept in the Sheep Research Unit of the Agricultural Research Farm of Erciyes University in the Kayseri Province (Turkey). The experiment lasted 56 days: 14 days of adaptation and 42 days of experimental period.

\section{Adaptation period}

The animals were housed in individual boxes $(200 \mathrm{~cm} \times 180 \mathrm{~cm} \times 120 \mathrm{~cm}$; height, length, width, respectively) equipped with feeders dispensing forage and concentrate feed separately, and an automatic drinker. The lambs were fed twice a day during adaptation and experimental periods. In adaptation period that lasted 2 weeks lambs got accustomed to the experimental diet. The level of concentrate feed was increased gradually during adaptation period. At day 1 , they were fed only lucerne hay (100\% of diet), and at the end of this period (day 14) - diet containing 70\% concentrate feed (pelleted form) and 30\% lucerne hay. 
All lambs were treated against internal and external parasites.

\section{Experimental period}

The animals were housed in the same boxes as in adaptation period. Through the whole experimental period, all lambs were fed diet containing about $70 \%$ of concentrate feed (Table 1) and $30 \%$ of lucerne hay. The diets were prepared by calculating the daily needs of lambs for dry matter and energy according to National Research Council (NRC, 2007). Diet and water were offered ad libitum.

Table 1. Ingredient composition of concentrate feed

\begin{tabular}{ll}
\hline Ingredients & Amount, \% \\
\hline Barley & 34.0 \\
Wheat & 22.0 \\
Maize & 20.0 \\
Wheat bran & 10.0 \\
Cotton seed meal (31\% CP) & 5.4 \\
Sugar beet molasses & 5.0 \\
Limestone (38\% Ca) & 2.5 \\
Di-calcium phosphate & 0.5 \\
Salt & 0.6 \\
\hline
\end{tabular}

The lambs were separated according to their LW into three groups; control - without TS essential oil dietary supplementation, and two treatment groups fed diet supplemented with 10 or $15 \mu \mathrm{l}$ of TS essential oil per kg of LW (Table 2). These levels of supplementation appeared to exert a positive effect on the digestion of concentrate feed in our previous study (Baytok et al., 2013). Essential oils were added to the concentrate feed daily using an automatic pipette before lambs feeding. Concentrate feed with TS essential oil was consumed readily. These calculations were carried out individually for each lamb in the treatment groups (Table 2). The TS essential oil was stored in a sealed thermos for protection against sunlight and high temperature.

Table 2. Calculation ${ }^{1}$ of daily amount of Thymbra spicata essential oil, $\mu \mathrm{l} \cdot$ day $^{-1}$

\begin{tabular}{ccc}
\hline \multirow{2}{*}{ Week } & \multicolumn{2}{c}{ Experimental groups (Thymbra spicata essential oil) } \\
\cline { 2 - 3 } & $\begin{array}{l}10 \mu \mathrm{\mu l} \cdot \mathrm{kg}^{-1} \mathrm{LW} \\
(\mathrm{n}=5)\end{array}$ & $\begin{array}{l}15 \mu \mathrm{\mu l} \cdot \mathrm{kg}^{-1} \mathrm{LW} \\
(\mathrm{n}=5)\end{array}$ \\
\hline as daily amount, $\mu \mathrm{l} \cdot$ day $^{-1}$ & \\
1 & 384 & 572 \\
2 & 402 & 600 \\
3 & 418 & 621 \\
4 & 430 & 642 \\
5 & 453 & 677 \\
6 & 476 & 712 \\
\hline
\end{tabular}

1 - calculations were fitted individually for each lamb. Values are the average of 5 lambs for both treatment groups; LW - live weight
The individual forage or concentrate feed intake of lambs was determined daily [feed intake, $\mathrm{g}=$ (provided feed, $\mathrm{g}-$ feed residues, $\mathrm{g}$ )]. Live weight was determined weekly and LW gain was calculated.

\section{Rumen fluid characteristics}

At the end of the study, samples of the rumen fluid from each lamb were collected into 2 sterile glass bottles ( $50 \mathrm{~g}$ per bottle) using a stomach tube $3 \mathrm{~h}$ after the morning feeding.

The $\mathrm{pH}$ value of the rumen fluid was determined using a digital $\mathrm{pH}$ meter (Mettler Toledo S220; Mettler Toledo, Greifensee, Switzerland). The ammonia-N $\left(\mathrm{NH}_{3}-\mathrm{N}, \mathrm{mg} \cdot 1^{-1}\right)$ concentration of the rumen medium was estimated by a distillation method (Makkar and Becker, 1996). Briefly, after centrifugation at $1000 \mathrm{~g}$ for $15 \mathrm{~min}$ the samples were subjected to the distillation with potassium hydroxide $(2 \mathrm{~N})$ without prior acid digestion. The liberated $\mathrm{NH}_{3}$ was collected in flasks with boric acid and titrated with diluted hydrochloric acid (0.1 N) (Souza et al., 2010).

Ruminal volatile fatty acids (VFA) [acetic (A), propionic $(\mathrm{P})$ and butyric (B) acids, mmol $\cdot \mathrm{l}^{-1}$ of rumen fluid] concentration was assessed by $\mathrm{GC}$ (TRACETM 1300 GC, Thermo Fisher Scientific, Waltham, MA, USA) equipped with a flame ionisation detector as described by Erwin et al. (1961). The ruminal fluid was filtered through 4 layers of cheesecloth, mixed with $25 \%(\mathrm{w} / \mathrm{v})$ meta-phosphoric acid and kept frozen $\left(-20^{\circ} \mathrm{C}\right)$ for the further analysis of VFA. The frozen samples were thawed at $4{ }^{\circ} \mathrm{C}$ and centrifuged. The analysis was performed under the following conditions: wax column (TraceGOLD ${ }^{\mathrm{TM}}$ TG-WaxMS, length $60 \mathrm{~m}$, diameter $0.25 \mathrm{~mm}$, film thickness $1.25 \mu \mathrm{m}$ ); injector and detector temperature $240{ }^{\circ} \mathrm{C}$; stove heat program, from $80^{\circ} \mathrm{C}(1 \mathrm{~min}$ hold $)$ to $240{ }^{\circ} \mathrm{C}$ rising at $10^{\circ} \mathrm{C} \cdot \mathrm{min}^{-1}$ and held for $20 \mathrm{~min}$ at $240{ }^{\circ} \mathrm{C}$; flow speed $15 \mathrm{psi}$; detector $70 \mathrm{eV}$; ionization type, EI; carrier gas: helium $\left(20 \mathrm{ml} \cdot \mathrm{min}^{-1}\right)$; sample injected $1 \mu$ l. Identification of constituents was carried out with the help of the retention times of standard substances (Fluka - Sigma Aldrich, St. Louis, MO, USA). Data were handled using the Xcalibur Software (Thermo Fisher Scientific, Waltham, MA, USA).

The concentration of selected and total VFA was determined as $\mathrm{mmol} \cdot \mathrm{I}^{-1}$. The individual acids proportions as the $\%$ in VFA and the $(\mathrm{A}+\mathrm{B})$ :P ratio were also calculated.

\section{Chemical analysis}

The samples of concentrate feed and lucerne hay were milled through a 1-mm sieve (MF 10 basic Microfine grinder drive, IKA ${ }^{\circledR}$-Werke GmbH \& Co. $\mathrm{KG}$, Staufen, Germany) for further use in chemical 
analysis. The analyses of concentrations of dry matter (DM), ash, crude protein (CP), and diethyl ether extract (EE) were provided according to AOAC International (2012), methods 934.01, 942.05, 954.01 and 920.39, respectively. The neutral detergent fibre (NDF), acid detergent fibre (ADF) and acid detergent lignin (ADL) contents were determined in approximately $1.0 \mathrm{~g}$ of samples by using a fibre analyser (FIWE3, VELP Scientifica, Usmate, Italy) according to Van Soest et al. (1991) method. The NDF was determined using $0.5 \mathrm{~g}$ of sodium sulphite and $200 \mu \mathrm{L}$ of thermo-stable $\alpha$-amylase (aNDF) (Megazyme, Wicklow, Ireland). Total aNDF, ADF and ADL contents were corrected for ash (aNDFom, ADFom and ADL, respectively). The total condensed tannins (TCT) content of the samples was determined by the butanol-HCl method according to Makkar et al. (1995) using a spectrophotometer (UviLine 8100, SI Analytics, Mainz, Germany). Analyses were carried out in duplicate (Table 3).

Table 3. Chemical composition of concentrate feed and lucerne hay

\begin{tabular}{lll}
\hline Indices, \% DM & Concentrate feed & Lucerne hay \\
\hline Crude protein & 12.70 & 10.23 \\
Ash & 7.82 & 8.61 \\
Ether extract & 3.13 & 1.30 \\
Crude fibre & 8.89 & 36.34 \\
aNDFom & 28.87 & 48.81 \\
ADFom & 12.47 & 41.27 \\
HC & 16.40 & 7.54 \\
ADL & 3.27 & 8.67 \\
TCT & 0.32 & 0.61 \\
\hline
\end{tabular}

aNDFom - neutral detergent fibre assayed with a heat stable amylase and expressed exclusive of residual ash; ADFom - acid detergent fibre expressed exclusive of residual ash; $\mathrm{HC}$ - hemicellulose (aNDFom ADFom); $A D L$ - acid detergent lignin determined by solubilisation of cellulose with sulphuric acid; TCT - total condensed tannin

\section{Statistical analysis}

The experimental data were firstly subjected to Levene's test to detect the variance homogeneity. One-way variance analysis (ANOVA) was implemented for homogeneous variances by General Linear Model procedures to test treatment differences. Data were analysed according to the following statistical model:

$$
\mathrm{Y} i j=\mu i j+\mathrm{S} i+\mathrm{e} i
$$

where: Yij - general mean common for each parameter under investigation, $\mu i j$ - general mean common of TS essential oil for each parameter under investigation, $\mathrm{S} i$ - effect of TS essential oil on the observed parameters, e $i$-standard error term.
The means were compared by Tukey's multiple range test at $P<0.05$. The data were presented as mean \pm standard error of mean.

Analyses were performed using SPSS 17.0 software (IBM Corp., Chicago, IL, USA).

\section{Results}

Essential oil of TS harvested at the beginning of flowering was determined to contain $66.86 \%$ carvacrol, $12.18 \% p$-cymene, $10.73 \% \gamma$-terpinene, $2.77 \%$ thymol and several other components (Table 4).

Table 4. Chemical composition of Thymbra spicata L. essential oil

\begin{tabular}{|c|c|c|c|}
\hline Compounds & $\%$ & $\mathrm{RI}^{1}$ & $\mathrm{RT}^{2}$ \\
\hline a-pinene & 0.56 & 1028 & 3.64 \\
\hline a-phellandrene & 0.64 & 1033 & 3.71 \\
\hline camphene & 0.06 & 1073 & 4.36 \\
\hline$\beta$-pinene & 0.10 & 1113 & 5.16 \\
\hline$\delta$-3-carene & 0.05 & 1155 & 6.10 \\
\hline$\beta$-myrcene & 1.04 & 1170 & 6.51 \\
\hline a-terpinene & 1.48 & 1184 & 6.90 \\
\hline dl-limonene & 0.17 & 1202 & 7.43 \\
\hline$\beta$-phellandrene & 0.12 & 1212 & 7.69 \\
\hline y-terpinene & 10.73 & 1252 & 8.86 \\
\hline p-cymene & 12.18 & 1276 & 9.69 \\
\hline a-terpinolene & 0.05 & 1286 & 10.04 \\
\hline oct-1-en-3-ol & 0.11 & 1454 & 16.17 \\
\hline trans sabinene hydrate & 0.05 & 1465 & 16.59 \\
\hline cis sabinene hydrate & 0.03 & 1547 & 19.73 \\
\hline linalool & 0.03 & 1551 & 19.91 \\
\hline trans caryophyllene & 1.28 & 1589 & 21.39 \\
\hline 4-terpineol & 0.53 & 1598 & 21.79 \\
\hline isoborneol & 0.21 & 1694 & 25.36 \\
\hline d-carvone & 0.02 & 1728 & 26.55 \\
\hline anethole & 0.04 & 1826 & 30.05 \\
\hline caryophyllene oxide & 0.65 & 1968 & 34.87 \\
\hline spathulenol & 0.15 & 2125 & 39.56 \\
\hline thymol & 2.77 & 2218 & 41.80 \\
\hline carvacrol & 66.86 & 2239 & 42.61 \\
\hline naphthalene ${ }^{3}$ & 0.08 & 2281 & 44.26 \\
\hline
\end{tabular}

${ }^{1} \mathrm{RI}$ - retention index; RT - retention time; ${ }^{2} \mathrm{RT}$ - retention time; ${ }^{3}$ naphthalene, 1,2,3,4,4a,5,6,7-octahydro-4a-methyl

There was no negative effect of both levels of TS essential oil dietary supplementation on LW, LW gain, feed intake (concentrate feed and lucerne hay) and feed conversion ratio $(P>0.05$; Table 5).

The $\mathrm{pH}$ values, $\mathrm{NH}_{3}-\mathrm{N}$ level $\left(\mathrm{mg} \mathrm{N} \cdot 1^{-1}\right)$, and molarities of $\mathrm{B}, \mathrm{P}$ and VFA $\left(\mathrm{mmol} \cdot \mathrm{1}^{-1}\right)$ in rumen fluid were not affected $(P>0.05)$ by the TS essential oil addition at both levels $\left(10\right.$ and $\left.15 \mu \mathrm{l} \cdot \mathrm{kg}^{-1}\right)$. On the other hand, molarity of $\mathrm{A}(P=0.024)$, the individual proportion $(\%)$ of $\mathrm{A}(P<0.001)$ and $(\mathrm{A}+\mathrm{B})$ : $\mathrm{P}$ ratio $(P=0.009)$ in the VFA of rumen fluid increased linearly with the increasing dose of TS essential 
Table 5. Effect of Thymbra spicata L. essential oil on some performance parameters in lambs

\begin{tabular}{|c|c|c|c|c|}
\hline & \multirow{2}{*}{ Control group } & \multicolumn{2}{|c|}{ Experimental groups (Thymbra spicata essential oil) } & \multirow{2}{*}{$P$-value } \\
\hline & & $10 \mu \mathrm{l} \cdot \mathrm{kg}^{-1} \mathrm{LW}$ & $15 \mu \mathrm{l} \cdot \mathrm{kg}^{-1} \mathrm{LW}$ & \\
\hline \multicolumn{5}{|l|}{ Live weight, kg } \\
\hline initial of experimental period & $38.41 \pm 1.78$ & $38.52 \pm 2.36$ & $38.14 \pm 1.41$ & 0.989 \\
\hline week 3 of experimental period & $43.03 \pm 1.66$ & $43.51 \pm 1.94$ & $42.83 \pm 1.84$ & 0.964 \\
\hline week 6 of experimental period & $47.62 \pm 2.01$ & $47.18 \pm 2.05$ & $47.48 \pm 1.53$ & 0.986 \\
\hline \multicolumn{5}{|l|}{ Live weight gain, $g \cdot$ day $^{-1}$} \\
\hline average of first 3 weeks & $220.20 \pm 0.67$ & $237.60 \pm 0.53$ & $223.30 \pm 0.62$ & 0.891 \\
\hline average of last 3 weeks & $218.70 \pm 0.19$ & $214.90 \pm 0.18$ & $221.50 \pm 0.14$ & 0.156 \\
\hline \multicolumn{5}{|l|}{ Concentrate feed intake, $\mathrm{g} \cdot$ day $^{-1}$} \\
\hline average of first 3 weeks & $1016.31 \pm 12.32$ & $1027.90 \pm 9.95$ & $1015.42 \pm 11.72$ & 0.696 \\
\hline average of last 3 weeks & $1084.20 \pm 9.08$ & $1086.41 \pm 10.36$ & $1086.00 \pm 9.67$ & 0.986 \\
\hline \multicolumn{5}{|l|}{ Lucerne hay intake, $g \cdot$ day $^{-1}$} \\
\hline average of first 3 weeks & $466.00 \pm 17.77$ & $458.00 \pm 16.62$ & $475.00 \pm 7.41$ & 0.722 \\
\hline average of last 3 weeks & $611.00 \pm 10.77$ & $619.00 \pm 9.53$ & $624.00 \pm 9.66$ & 0.661 \\
\hline \multicolumn{5}{|l|}{ Feed conversion ratio ${ }^{*}, g \cdot g^{-1}$} \\
\hline average of first 3 weeks & $6.73 \pm 0.16$ & $6.25 \pm 0.21$ & $6.67 \pm 0.18$ & 0.452 \\
\hline average of last 3 weeks & $7.75 \pm 0.42$ & $7.93 \pm 0.29$ & $7.72 \pm 0.34$ & 0.738 \\
\hline
\end{tabular}

* - calculated as dry matter intake (concentrate feed + lucerne hay)/ live weight gain; LW - live weight

Table 6. Effect of Thymbra spicata $\mathrm{L}$. essential oil on concentrations of organic acids, $\mathrm{NH}_{3}-\mathrm{N}$ and $\mathrm{pH}$ value in lamb rumen fluid

\begin{tabular}{|c|c|c|c|c|c|}
\hline \multirow{2}{*}{ Indices } & \multirow{2}{*}{ Control group } & \multicolumn{2}{|c|}{ Experimental groups (Thymbra spicata essential oil) } & \multicolumn{2}{|l|}{$P$-value } \\
\hline & & $10 \mu \mathrm{l} \cdot \mathrm{kg}^{-1} \mathrm{LW}$ & $15 \mu \mathrm{l} \cdot \mathrm{kg}^{-1} \mathrm{LW}$ & linear & quadratic \\
\hline \multicolumn{6}{|c|}{ Molarities in rumen fluid, $\mathrm{mmol} \cdot \mathrm{I}^{-1}$} \\
\hline acetic acid & $47.90 \pm 0.97$ & $47.80 \pm 0.82$ & $50.36 \pm 1.24$ & 0.024 & 0.319 \\
\hline propionic acid & $26.74 \pm 0.68$ & $26.14 \pm 0.26$ & $26.82 \pm 0.66$ & 0.928 & 0.385 \\
\hline butyric acid & $8.91 \pm 0.25$ & $8.92 \pm 0.30$ & $9.74 \pm 0.40$ & 0.103 & 0.333 \\
\hline VFA $^{1}$ & $83.55 \pm 1.86$ & $82.86 \pm 1.37$ & $86.91 \pm 2.15$ & 0.224 & 0.317 \\
\hline \multicolumn{6}{|c|}{ Individual proportions in total VFA, \% } \\
\hline acetic acid & $57.34 \pm 0.12$ & $57.69 \pm 0.05$ & $57.94 \pm 0.03$ & $<0.001$ & 0.629 \\
\hline propionic acid & $32.00 \pm 0.16$ & $31.55 \pm 0.21$ & $30.86 \pm 0.32$ & 0.008 & 0.679 \\
\hline butyric acid & $10.67 \pm 0.14$ & $10.76 \pm 0.19$ & $11.21 \pm 0.32$ & 0.135 & 0.543 \\
\hline$(A+B): P^{2}$ & $2.13 \pm 0.02$ & $2.17 \pm 0.02$ & $2.24 \pm 0.03$ & 0.009 & 0.652 \\
\hline $\mathrm{pH}$ & $6.91 \pm 0.19$ & $7.04 \pm 0.13$ & $7.06 \pm 0.15$ & 0.270 & 0.356 \\
\hline $\mathrm{NH}_{3}-\mathrm{N}, \mathrm{mg} \mathrm{N} \cdot \mathrm{I}^{-1}$ & $15.68 \pm 0.40$ & $17.88 \pm 1.51$ & $18.62 \pm 1.69$ & 0.154 & 0.664 \\
\hline
\end{tabular}

${ }^{1} \mathrm{VFA}$ - violate fatty acids = acetic + propionic + butyric acids as $\mathrm{mmol} \cdot \mathrm{I}^{-1}$ in rumen fluid; ${ }^{2}(\mathrm{~A}+\mathrm{B}): \mathrm{P}=($ acetic acid + butyric acid $) /$ propionic acid as $\mathrm{mmol} \cdot \mathrm{I}^{-1} ; \mathrm{LW}$ - live weight

oil. In addition, the individual proportion (\%) of $\mathrm{P}$ $(P=0.008)$ in rumen fluid decreased linearly with the levels of TS essential oil addition (Table 6).

\section{Discussion}

The essential oils (or secondary metabolites) extracted from aromatic plants have different biological activities in human and animal organisms depending on the genus of the aromatic plant and the amount of secondary metabolites (Benchaar et al.,
2006; Ali et al., 2015; Calo et al., 2015). In the present study, the most common component in the essential oil of TS at the early flowering stage was carvacrol $(66.86 \%)$. Other high compounds were terpinolen isomeric hydrocarbons $(\alpha$-terpinene $+\gamma$-terpinene, $10.73+1.48 \%$, respectively) and $p$-cymene aromatic hydrocarbon (12.18\%). İnan et al. (2011) demonstrated that the levels of TS essential oil components varied from 53.55 to $64.53 \%$ for carvacrol, from 14.29 to $19.45 \%$ for $\gamma$-terpinene and from 7.06 to $10.34 \%$ for $p$-cymene according to the plant 
developmental stage and this was confirmed in our study. Ünlü et al. (2009) stated that the TS essential oil was characterised by a high content of the phenolic carvacrol $(60.39 \%)$ and other major compounds as monoterpenic hydrocarbons: $\gamma$-terpinene $(12.95 \%)$ and $p$-cymene $(9.61 \%)$. So, the most common secondary compounds in TS essential oil are the monoterpenic hydrocarbons: $\gamma$-terpinene and $p$-cymene, which has been confirmed by the results of previously mentioned and current study.

Tümen et al. (1994) studied the compositions of Thymbra spicata var. spicata and Thymbra spicata var. intricata (endemic in Turkey) which vary in different regions of Turkey and show that the composition of TS essential oil show large variations in the relative concentration of major components: carvacrol $(9.10-76.86 \%), \gamma$-terpinene $(5.35-22.33 \%)$ and $p$-cymene (5.49-23.54\%). In the studies carried out on TS it was observed that the chemical composition of essential oil might depend on harvesting seasons, geographical locations, processing, storage conditions and parts of the plants.

The plant extracts used in ruminant nutrition are considered as natural manipulators of rumen fermentation and digestibility due to their physiological and pharmacological effects. In this study, the addition of TS essential oil at the levels of 10 and $15 \mu 1$ per $\mathrm{kg}$ LW of lambs did not adversely affect LW or LW gain. The intake of concentrate feed and lucerne hay was similar which is in accordance with the results of other in vivo studies examining thyme oil and active compounds of this genus (carvacrol, thymol, $\gamma$-terpenene and $p$-cymene) (Bampidis et al., 2005; Chaves et al., 2008; Wang et al., 2009; Vakili et al., 2013). Simitzis et al. (2008) also observed that supplementation of concentrate feed oregano essential oil $\left(1 \mathrm{ml} \cdot \mathrm{kg}^{-1}\right)$ did not affect LW or LW gain. Biricik et al. (2016) found that supplementation of carvacrol ( 100 or $\left.300 \mathrm{mg} \cdot \mathrm{kg}^{-1}\right)$, thymol $\left(100\right.$ or $300 \mathrm{mg} \cdot \mathrm{kg}^{-1}$ ) or their mixtures $\left(100\right.$ or $\left.300 \mathrm{mg} \cdot \mathrm{kg}^{-1}\right)$ to the diet of fattening lambs did not affect feed intake, LW, LW gain and feed conversion ratio.

In the present study, the individual molarities of $\mathrm{B}, \mathrm{P}$ and total VFA, $\mathrm{NH}_{3}-\mathrm{N}$ concentration and the $\mathrm{pH}$ value of rumen were not influenced after the supplementation with TS essential oil. Wang et al. (2009) also reported that the addition of oregano oil at the dose of $250 \mathrm{mg} \cdot \mathrm{d}^{-1}$ into sheep diet did not affect the ruminal $\mathrm{pH}$ and $\mathrm{A}: \mathrm{P}$ ratio, but increased VFA content and decreased $\mathrm{NH}_{3}-\mathrm{N}$ concentration. Chaves et al. (2008) found that carvacrol (purity $>98 \%$ ) supplementation at the level of $0.2 \mathrm{~g} \cdot \mathrm{kg}^{-1} \mathrm{DM}$ reduced ruminal $\mathrm{pH}$, increased VFA and did not change $\mathrm{A}: \mathrm{P}$ ratio or $\mathrm{NH}_{3}-\mathrm{N}$ level in lambs. Besides, thyme essential oil $\left(5 \mathrm{~g} \cdot \mathrm{d}^{-1} \cdot\right.$ calf $\left.^{-1}\right)$ supplementation to growing calves diet (15\% lucerne hay and 85\% concentrate feed) did not affect $\mathrm{pH}$ value, concentration of $\mathrm{NH}_{3}-\mathrm{N}$ and molar concentration of VFA in rumen fluid; whereas decreased the molar proportion of acetate and A:P ratio, and increased the molar proportion of propionate (Vakili et al., 2013). In another study, addition of Origanum vulgare oil (rich in carvacrol) into lamb diet increased $\mathrm{pH}$ value, $\mathrm{NH}_{3}-\mathrm{N}$ concentration, and the molar concentration of VFA in rumen fluid (Biricik et al., 2016). The differences observed in these studies could be attributed to such factors as the method of essential oil supplementation, the time of addition (just before feeding), the content of the active compound, the ambient temperature and the amount of other active compounds present in the diet.

\section{Conclusions}

Thymbra essential oil has a positive effect on the digestion of the diet, thus increasing the concentration of selected volatile fatty acids in the rumen liquid. In particular, a linear increase in the molarity of acetic acid and (acetic + butyric):propionic acid ratio in rumen fluid of lambs fed diet supplemented with Thymbra spicata essential oil may indicate an increase in fibrolitic activity in the rumen ecosystem. It may be advisable that these essential oils which are characterized by high carvacrol, $p$-cymene, $\gamma$-terpinene contents can be used as a functional additive in lamb diets. Nevertheless, antiprotozoal and antimicrobial properties of Thymbra spicata essential oil in rumen should be further investigated by using different doses and in further in vivo studies of greater duration.

\section{Acknowledgement}

This study was supported by Project No. TOA12-3940 granted by the Research Fund of Erciyes University, Kayseri (Turkey), and was presented orally during $1^{\text {st }}$ International Animal Nutrition Congress, 28 September - 1 October 2016, the province of Antalya (Turkey).

\section{References}

AOAC International, 2012. Official Methods of Analysis of AOAC International. 19th Edition. Gaithersburg, MD (USA)

Ali B., Al-Wabel N.A., Shams S., Ahamad A., Khan S.A., Anwar F., 2015. Essential oils used in aromatherapy: A systemic review. Asian Pac. J. Trop. Biomed. 5, 601-611, https://doi. org/10.1016/j.apjtb.2015.05.007 
Bampidis V.A., Christodoulou V., Florou-Paneri P., Christaki E., Spais A.B., Chatzopoulou P.S., 2005. Effect of dietary dried oregano leaves supplementation on performance and carcass characteristics of growing lambs. Anim. Feed Sci Technol. 121, 285-295, https://doi.org/10.1016/j.anifeedsci.2005.02.002

Başer K.H.C., 1995. Essential oils from aromatic plants which are used as herbal tea in Turkey. In: Proceedings of the $13^{\text {th }}$ International Congress of Flavours, Fragrances and Essential Oils. Istanbul (Turkey)

Başer K.H.C., 2002. Aromatic biodiversity among the flowering plant taxa of Turkey. Pure Appl. Chem. 74, 527-545, https://doi. org/10.1351/pac200274040527

Başer K.H.C., Özek T., Tümen G., Sezik E., 1994. Essential oils of Turkish Origanum species, which are of a commercial importance. TAB Bult. 10, 28-30

Baytok E., Kara K., Aksu T., Güçlü B.K., Denek N., Yörük M.A., Kaya D.A., Kamalak A., Akçay A., Önal S.E., 2013. Determining the impact of thyme (Thymbra spicata L.) essential oil on performance and rumen metabolites in ruminants by in vitro and in vivo techniques and evaluating this impact for environment. I. In vitro digestion, rumen fermentation and methane production of dairy and beef cattle rations. In: Proceeding of VII ${ }^{\text {th }}$ National Animal Nutrition Congress, Ankara (Turkey), pp. 274-283

Benchaar C., Duynisveld J.L., Charmley E., 2006. Effects of monensin and increasing dose levels of a mixture of essential oil compounds on intake, digestion and growth performance of beef cattle. Can. J. Anim. Sci. 86, 91-96, https://doi.org/10.4141/ A05-027

Biricik H., Oral H.H., Taluğ A.M., Cengiz Ş.Ş., Koyuncu M., Dikmen S., 2016. The effects of carvacrol and/or thymol on the performance, blood and rumen parameters, and carcass traits of Merino sheep. Turk. J. Vet. Anim. Sci. 40, 651-659, https:// doi.org/10.3906/vet-1601-53

Calo J.R., Crandall P.G., O'Bryan C.A., Ricke S.C., 2015. Essential oils as antimicrobials in food systems - A review. Food Control 54, 111-119, https://doi.org/10.1016/j.foodcont.2014.12.040

Chaves A.V., Stanford K., Gibson L.L., McAllister T.A., Benchaar C., 2008. Effects of carvacrol and cinnamaldehyde on intake, rumen fermentation, growth performance, and carcass characteristics of growing lambs. Anim. Feed Sci. Techol. 145, 396-408, https://doi.org/10.1016/j.anifeedsci.2007.04.016

Erwin E.S., Marco G.J., Emery E.M., 1961. Volatile fatty acid analyses of blood and rumen fluid by gas chromatography. J. Dairy Sci. 44, 1768-1771, https://doi.org/10.3168/jds.S00220302(61)89956-6

Franz C., Baser K.H.C., Windisch W., 2010. Essential oils and aromatic plants in animal feeding - a European perspective. A review. Flavour Frag. J. 25, 327-340, https://doi.org/10.1002/ffj.1967

Hancı S.S., Sahin S., Yılmaz L., 2003. Isolation of volatile oil from thyme (Thymbra spicata) by steam distillation. Nahr. - Food 47, 252-255, https://doi.org/10.1002/food.200390059

İnan M., Kirpik M., Kaya D.A., Kirici S., 2011. Effect of harvest time on essential oil composition of Thymbra spicata L. growing in flora of Adıyaman. Adv. Environ. Biol. 5, 356-358
Kara K., 2015. In vitro methane production and quality of corn silage treated with maleic acid. Ital. J. Anim. Sci. 14, 3994, https:// doi.org/10.4081/ijas.2015.3994

Kara K., Güçlü B.K., Baytok E, 2015. Comparison of nutrient composition and anti-methanogenic properties of different Rosaceae species. J. Anim Feed Sci. 24, 308-314, https://doi. org/10.22358/jafs/65613/2015

Makkar H.P.S., Becker K., 1996. Nutrional value and antinutritional components of whole and ethanol extracted Moringa oleifera leaves. Anim. Feed Sci. Technol. 63, 211-228, https://doi. org/10.1016/S0377-8401(96)01023-1

Makkar H.P.S., Blümmel M., Becker K., 1995. Formation of complexes between polyvinyl pyrrolidones or polyethylene glycols and tannins, and their implication in gas production and true digestibility in vitro techniques. Br. J. Nutr. 73, 897-913, https:// doi.org/10.1079/BJN19950095

NRC, 2007. Nutrient Requirements of Small Ruminants: Sheep, Goats, Cervids, and New World Camelids. The National Academies Press. Washington, DC (USA), https://doi. org/10.17226/11654

Önenç S.S., 2008. Effects of some aromatic plants on in vitro rumen fermentation. PhD Thesis. Ege University, Graduate School of Natural and Applied Sciences. İzmir (Turkey)

Simitzis P.E., Deligeorgis S.G., Bizelis J.A., Dardamani A., Theodosiou I., Fegeros K., 2008. Effect of dietary oregano oil supplementation on lamb meat characteristics. Meat Sci. 79, 217-223, https://doi.org/10.1016/j.meatsci.2007.09.005

Souza M.A., Detmann E., Paulino M.F., Sampaio C.B., Lazzarini I., Filho S.C.V., 2010. Intake, digestibility and rumen dynamics of neutral detergent fibre in cattle fed low-quality tropical forage and supplemented with nitrogen and/or starch. Trop. Anim. Health Prod. 42, 1299-1310, https://doi.org/10.1007/ s11250-010-9566-6

Tümen G., Ermin N., Özek T., Kürkçüoglu M., Baser K.H.C., 1994. Composition of essential oils from two varieties of Thymbra spicata L. J. Essent. Oil Res. 6, 463-468, https://doi.org/10.1 080/10412905.1994.9698427

Ünlü M., Vardar-Ünlü G., Vural N., Dönmez E., Özbaş Z.Y., 2009. Chemical composition, antibacterial and antifungal activity of the essential oil of Thymbra spicata L. from Turkey. Nat. Prod. Res. 23, 572-579, https://doi.org/10.1080/14786410802312316

Vakili A.R., Khorrami B., Danesh Mesgaran M., Parand E., 2013. The effects of thyme and cinnamon essential oils on performance, rumen fermentation and blood metabolites in Holstein calves consuming high concentrate diet. Asian Australas. J. Anim. Sci. 26, 935-944, https://doi.org/10.5713/ajas.2012.12636

Van Soest P.J., Robertson J.B., Lewis B.A., 1991. Methods for dietary fiber, neutral detergent fiber, and nonstarch polysaccharides in relation to animal nutrition. J. Dairy Sci. 74, 3583-3597, https://doi.org/10.3168/jds.S0022-0302(91)78551-2

Wang C.J., Wang S.P., Zhou H., 2009. Influences of flavomycin, ropadiar, and saponin on nutrient digestibility, rumen fermentation and methane emission from sheep. Anim. Feed Sci. Technol. 148, 157-166, https://doi.org/10.1016/j.anifeedsci.2008.03.008 